Şırnak Üniversitesi

İlahiyat Fakültesi Dergisi

Cilt: 11, Sayı: 25, Aralık 2020

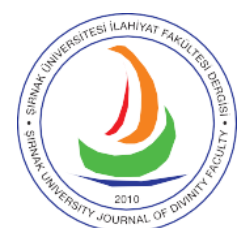

e-ISSN 2667-6575
Arap Hristiyanlığı: Kısa Bir Tarih

Arab Christianity: A Short History

\title{
Alexander TREIGER
}

Doç. Dr., Dalhousie Üniversitesi, Dinî Araştırmalar Programı Assistant Professor, Dalhousie University, Religious Studies Program

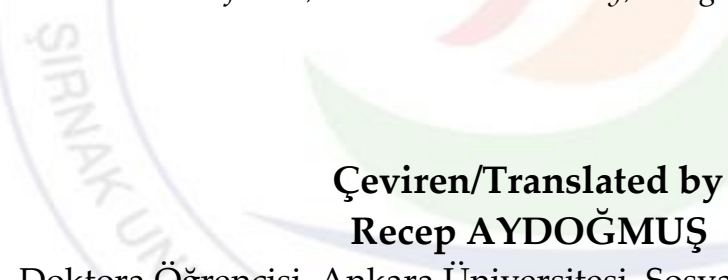

Doktora Öğrencisi, Ankara Üniversitesi, Sosyal Bilimler Enstitüsü, recep 1994 ist@hotmail.com https://orcid.org/0000-0003-4791-470X

\section{Makale Bilgisi / Article Information}

Makale Türü / Article Types: Çeviri / Translation

Geliş Tarihi / Received: 14 Temmuz/ July 2020

Kabul Tarihi / Accepted: 9 Kasım/ November 2020

Yayın Tarihi / Published: 15 Aralık / December 2020

Cilt / Volume: 11 Sayı / Issue: 25 Sayfa / Pages: 763-786

Atıf / Cite as: Treiger, Alexander. "Arap Hristiyanlığı: Kısa Bir Tarih [Arab Christianity: A Short History]". çev. Recep Aydoğmuş. Şırnak Üniversitesi Illahiyat Fakültesi Dergisi - Şırnak University Journal of Divinity Faculty 11/25 (December 2020), 763-786. https://doi.org/10.35415/sirnakifd.769616

Etik Beyanı / Ethics Declaration: Bu makalede bilimsel araştırma ve yayın etiği ilkelerine riayet edilmiştir. İlgili kurumdan çeviri izin onayı alınmıştır. Makale etik izin gerektirmeyen bir çalışma olup en az iki hakem tarafından incelenmiş ve intihal içermediği teyit edilmiştir./ In this article, the principles of scientific research and publication ethics are respected. Translation permission approval was obtained from the relevant institution. The article is a study that does not require ethical permission. It has been reviewed by at least two referees and was confirmed that it did not contain plagiarism.

Copyright $@$ Published by Şırnak Üniversitesi, İlahiyat Fakültesi / Şırnak, Türkiye (Şırnak University, Faculty of Divinity, Şırnak, 73000 Turkey). 


\section{Giriş $^{1}$}

Arapça konuşanlar, İncil'in vaazını işiten ilk halklar arasındaydı. ${ }^{2}$ Onlar ilk Pentakost' $\mathrm{a}^{3}$ şahitlik ettiler ve vizyon geçirdikten hemen sonra Arabistan'1 (Bugünkü Ürdün) ziyaret eden havari Pavlus'u işittiler. ${ }^{4}$ İslam'ın ortaya çıkışından önce her ne kadar birkaç Arap kabilesi Hıristiyanlığı kabul etmiş ve hiç şüphesiz Arapçayı kendi dini pratiklerinde kullanmış olsalar da Arapçanın Hıristiyan yazınsal dili olarak kullanımı, İslam'ın Ortadoğu'yu fethi ile başlad1..$^{5}$ On üç yüzyıldan daha fazladır, yedinci yüzyıldan günümüze kadar, büyük ölçüde İslam'ın tanımladığı bir dilde Hıristiyan inancını dile getirme ve ilan etme mücadelesi, Arap topraklarındaki Hıristiyan toplumların özgün karakterlerinin büyük kısminı oluşturdu.

\section{Arap Hristiyanlı̆̆ı: Kısa Bir Tarih}

\section{1. İslam'dan Önce ve Kuran'da Arap Hıristiyanlığı}

Arap topraklarındaki Hıristiyanların soyu iki tür topluluktan gelmektedir. İslam'ın ortaya çıkışından önce Hıristiyanlığı kabul eden bedevî ve hadarî Araplar ile çok daha büyük oranda İslamî fetihlerle beraber zamanla Araplaşmış, aslen Âramîce (Süryanîce), Grekçe ya da Kıptîce konuşan Ortadoğu yerlisi Hıristiyan topluluklar.

Arap yarımadası sınırlarındaki Arap kabilelerinin Hıristiyanlaşması İslam'dan çok önce başladı. Gassâniler Arabistan'ın kuzeyinde, Lahmîler ise Kuzeydoğusunda beşinci yüzyıla kadar sırasıyla Miafizit ve "Nestûrî" oldular ve Bizans ile Sâsânileri Arap istilalarına

1 Bu makalenin kaynağı için bk. Augustine Casiday (ed.). The Orthodox Christian World (London: Routledge, 2012), 89-104.

2 Samuel Noble'a (Yale Üniversitesi) bu makalenin ilk taslakları hakkında yaptığı değerli yorumları, önemli referansları ve birkaç paragrafın okunuşu hakkında yaptığı nazik yardımından ötürü minnettarım.

3 Elçilerin İşleri, 2/11.

4 Galatyalılar, 1/17.

5 Her ne kadar tamamı güncel olmasa da Georg Graf'ın "Geschichte der christlichen arabischen Literatur" (Hıristiyan Arap Literatürü Tarihi) (1944-53) isimli devasa eseri Hıristiyan Arap literatürünün klasik eseri olarak kalmaya devam ediyor. Arap Ortodoks toplumu literatürü için Graf'ın Geschichte isimli eseri J. Nasrallah 1983-89 ve 1996 (diğer ciltler henüz yayımlanmamış) ile birlikte kullanılır; ayrıca bk. Noble ve Treiger, The Orthodox Church in the Arab World (700-1700): An Anthology of Sources, 2014 ve Panchenko, Blizhnevostochnoe Pravoslavie pod osmanskim vladychestvom: Pervye tri stoletija (1516-1831), 2012. Müslüman-Hıristiyan ilişkileri ile ilgili metinler için D. Thomas, B. Roggema ve A. Mallett, Christian-Muslim Relations: A Bibliographical History, 2009 vazgeçilmezdir. Hıristiyan Arap literatürü hakkındaki aşağıdaki kısa araştırmalar yararlıdır: Coquin, Arabic Christian Literature, 2000; Samir, Christian Arabic Literature in the 'Abbasid Period, 1991; D. Thomas, Arab Christianity, 2007; Troupeau, La littérature arabe chrétienne du Xe au XIIe siècle, 1971. Ayrıca Teule ve Schepens'e, Christian Arabic Bibliography 1990-95, 2005; Christian Arabic Bibliography 1996-2000, 2006 ve Christian Arabic Bibliography 2001-2005, 2010 bakınız. 
karşı koruyan "tampon devletler" olarak işlev gördüler. ${ }^{6}$ Nesturi Hıristiyanlığı İran körfezi kıyıları boyunca Beyt Qatraye'nin sahil kesiminde yaşamaktaydı. (Yedinci yüzyılın meşhur Doğu Süryani münzevi yazarı Süryani İshak bu bölgeden gelir.) $)^{7}$ Güneybatı Arabistan'daki Necran Vahasında Aksum Etiyopya Krallığına bağlı büyüyen bir Miafizit Hıristiyan topluluğu vardı. Necran Hıristiyanları 523 yılında Yahudi Kralı Yusuf Zûnüvâs'ın zulmüne maruz kaldı ve kralları Haris dâhil birkaç yüz Hıristiyan şehit edildi. ${ }^{8}$ Bunun devamında Etiyopya'dan gelen askeri müdahalenin ardından Necran'daki Hiristiyanlık yeniden toparlandı ve bu toplum, İslam'ın ikinci halifesi Ömer (634-644) tarafından Arabistan'dan nihai olarak çıkartılana kadar varlığını sürdürdü.

Yedinci yüzyılın başlarında Arabistan'ın merkezi Hicaz ve Necd'de de bir miktar Hıristiyan varlığı söz konusuydu ve inancını değiştiren insanları hidayet etmek için oldukça belirgindiler. Nitekim Müslüman geleneği bize örneğin, Hz. Muhammed'in ilk hanımının kuzeni Varaka b. Nevfel'in İslam'dan önce Hiristiyan olduğunu ve Hiristiyan kutsal metinleri konusunda oldukça bilgili olduğunu anlatır. ${ }^{9}$ Bu anlatım, Hz. Muhammed'in peygamberliğinin bir Hıristiyan tarafından onaylanması şeklinde apolojik amaçlarla kullanılmış olmasına rağmen, yine de Müslüman tarihçilerin İslam peygamberinin bir akrabasının Hıristiyanlığa geçmiş olduğunu makul kabul etmeleri açısından dikkat çekicidir.

Kuran sık sık Hristiyanlara, ki bunlar Arap Yarımadası'nın Hristiyan Araplarıdır, değinir, onları muhatap alır ve onlara karşı polemik yapar. (Onlara "en-Nasârâ", “Nasıralılar" ya da bir ayette "Ehlü'l-İncîl”, yani "İncil Halkı" der.) Her ne kadar geçmişte bu Hıristiyanların, Hıristiyanlığın heretik bir versiyonunu benimsediklerine dair görüşler olsa da, söz gelimi Meryem'in teslisin unsurlarından biri kabul edilmesi gibi, şu an bu Hıristiyan Arapların, elbette yedinci yüzyılın başlarından sonra ortaya çıkan mezhepler

6 T. Hainthaler, Christliche Araber vor dem Islam: Verbreitung und konfessionelle Zugehörigkeit, (Leuven: Peeters, 2007.)

7 Sebastian Brock, "From Qatar to Tokyo, by Way of Mar Saba: The Translations of Isaac of Beth Qatraye (Isaac the Syrian)", ARAM 11-12 (1999-2000), 475-84 ve Sebastian Brock, "Syriac Authors from Beth Qatraye", ARAM 11-12 (1999-2000), 85-96.

8 Irfan Shahid, The Martyrs of Najran: New Documents, Société des Bollandistes, (Brussels: 1971) ve J. Beaucamp vd., "La persecution des chretiens de Nagran et la chronologie himyarite", ARAM 11-12 (19992000), 15-83.

9 C. F. Robinson, “Waraka b. Nawfal”, Encyclopaedia of Islam, (Leiden: Brill, 2000-2002), 11/142-143 ve G. Osman, "Pre-Islamic Arab Converts to Christianity in Mecca and Medina", Muslim World 95/1 (2005), 67-80. 
istisna olmak üzere, günümüzde bildiğimiz Ortadoğu Hıristiyanlığıyla aynı mezheplere bağlı oldukları genel olarak kabul edilmektedir.10

Kuran, her ne kadar Hıristiyanları Yahudiler ve diğer bazı dini gruplarla beraber “Ehli Kitap" arasında kabul etse ve hatta Hıristiyanların Müslümanlara karşı Yahudilerden ve müşriklerden daha yakın olduklarını bildirse de, "çünkü onlar içinde keşişler ve rahipler vardır ve onlar büyüklük taslamazlar"(el-Mâide 5/82) yine de Hıristiyanlığın temel inanç esaslarına karşı oldukça eleştireldir. Kuran, teslis (el-Mâide 5/73) ve enkarnasyon şeklindeki Hristiyan görüşlerini reddeder. İsa'yı “Mesîh”, “Tanrının elçisi” hatta “Meryem'e ilka ettiği Tanrı kelamı" ve “Tanrıdan bir ruh" olarak ele almakla beraber yine de o, İsa'nın Tanrığlu ve Tanrısal olduğunu kesin olarak reddeder; Mesih'in tanrısallığı hakkındaki Hristiyan inancı haksız bir aşırılık olarak ele alınır (en-Nisâ 4/171). Kuran İsa'nın bir bakireden doğduğunu (Meryem 19/22) mucizeler gösterdiğini ve “Kutsal Ruh" ile desteklendiğini (elBakara 2/87, 253; el-Mâide 5/110) (çoğunlukla melek Cebrail ile eşit görülmüştür) doğrular; fakat onun çarmıhta öldüğünü ve ölümden dirildiğini reddeder. Çok bilinen bir Kuran ayetidoketik bir tarzda- İsa'nın insanlara sadece çarmıha gerilmiş gibi göründüğünü iddia eder; gerçekte ise Tanrı onu kendi katına yükseltmiştir (en-Nisâ 4/157). Bu nokta yüzyıllar boyunca Hıristiyan-Müslüman polemiklerinde bıktıracak ölçüde tekrar edilecektir.

\section{2. İslam Fetihleri ve Ortadoğu Hıristiyanlığına Etkileri}

Ortadoğu'daki İslam fetihlerinin ardından, “Oryantal” patriklikler şeklinde de isimlendirilen İskenderiye, Antakya ve Kudüs Hıristiyanları, yine Sâsâni İmparatorluğu, Kuzey Afrika ve İspanya Hıristiyanları-ki dünyadaki Hıristiyan nüfusunun yaklaşık yüzde ellisi olduğu tahmin edilmektedir- kendilerini İslam yönetiminin altında buldular. ${ }^{11}$

$\mathrm{Bu}$, birkaç yönden yeni bir realite yarattı. İlk olarak, Yahudiler ve diğer dini topluluklar gibi Hristiyanlar da gelişen İslam imparatorluğu içinde "bağımlı azınlıklar" oldular (ehlü'z-zimme ya da zimmîler).12 Baş vergisi (cizye) ödeme karşılığında dinî özerklik tanınmış ve askerlik hizmetinden muaf tutulmuş olmakla beraber yine de onlar bir takım katı kısıtlamalara tabi tutuldular. Bu kısıtlamalar eski kilise ve manastırları restore etmeme ve yenilerini inşa etmeme, Müslümanlar arasında dinlerini yaymama, akrabası olsa dahi hiç

\footnotetext{
10 S. Griffith, "Syriacisms in the "Arabic Qur'an": Who Were Those Who Said "Allah Is Third of Three" according to al-Ma'ida 73?", A Word Fitly Spoken, ed. M.M. Bar-Asher vd. (Jerusalem: Mekhon Ben-Tsevi leheker kehilot Yisra'el ba-Mizrah, 2007), 83-110.

11 S. Griffith, The Church in the Shadow of the Mosque: Christians and Muslims in the World of Islam (Princeton: NJ: Princeton University Press, 2008), 11.

12 A. Fattal, Le statut légal des non-musulmans en pays d'Islam (Beirut: Imprimerie Catholique, 1995)
} 
kimsenin İslam'a girmesine engel olmama yasaklarını içermekteydi. Hıristiyanlar ayrıca ata binmekten, kılıç taşımaktan ve daha genel kapsamda giyim, konuşma ve davranışların da Müslümanlara benzemekten menedilmişlerdi. Bunun yerine onlardan karakteristik bir kemeri de kapsayan (zünnar, Grekçe zonarion kelimesinden gelir) kendilerine özgü elbiseler giymeleri ve kendilerini Müslümanlardan ayırt etmeleri bekleniyordu. Düzenli bir şekilde uygulanmamakla beraber bu kurallar, yine de her zaman kitaplarda yer aldı ve Müslüman yöneticilerin takdirine bağlı olarak herhangi bir zamanda uygulanabildi; söz gelimi Abbasi halifesi Mütevekkil (847-861) ve Fâtımî halifesi Hâkim (996-1021) tarafından büyük bir gaddarlıkla uygulandığı gibi.

İkinci olarak, eskiden Bizans'ın doğu illerinde yaşayan Hıristiyan topluluklar ile Bizans'ın geri kalanı arasındaki bağlar koptu ya da en azından sürdürülmesi zorlaştı ve bu topluluklar ilk defa kendilerini daha doğuda, önceki Sasani topraklarında yaşayan Hıristiyanlarla tek devlet yönetimi altında entegre olmuş buldular. Kadıköy görüşünü savunanları destekleyip, Miafizit görüşü benimseyenlere zulmeden Bizanslılar ile Doğu Kilisesi'ni destekleyen Sâsânilerin aksine Müslüman yöneticiler kiliseler arası bölünmeleri önemsemediler ve çeşitli Hristiyan gruplar arasında ayrımcılık yapmadılar. ${ }^{13} \mathrm{Bu}$, farklı inançlara sahip Hristiyanların kendi doktrinlerini rakip Hıristiyan gruplar ve yine Müslümanlar tarafından gelen saldırılara karşı savunmak ve bu gruplara karşı polemik yapabilmek amacıyla politik güç ve tanınırlık adına rekabet etmek zorunda oldukları bir durum yarattı. Böylece hem Hıristiyanlar arası hem de Hıristiyanlar ve Müslümanlar arası polemikler İslamî dönemde Hiristiyan dini literatürünün göze çarpan bir özelliği oldu.

Üçüncü olarak, İslam fetihlerinden sonra Müslüman imparatorluğu dönemi boyunca Hıristiyan nüfusun Araplaştırılması süreci başlamış oldu. Bu olguya karşı tepkiler karışıktı. Müslüman İspanya'sında Paulus Alvarus (ö. 860) Hiristiyanların Latinceyi unutup onun yerine Arapçayı benimsemelerinden yakındı. ${ }^{14}$ Benzer yakınmalar Kıptîce ile ilgili olarak Mısır'a ait Kalamunlu Samuel'in Kehanetleri'nde (aslen Kıptîce yazılan fakat ironik olarak günümüze Arapça olarak ulaşan bir metin) seslendirilmişti. ${ }^{15}$ Öte yandan henüz sekizinci yüzyılda, Filistin manastırlarındaki Kadıköy yanlıları edebi bir dil ve teolojik açılamaların

13 M. Morony, Iraq after the Muslim Conquest (Piscataway: NJ: Gorgias Press, 2005), 346.

14 Griffith, The Church in the Shadow of the Mosque, 152.

15 Bk. J. R. Zaborowski, "From Coptic to Arabic in Medieval Egypt”, Medieval Encounters 14/1 (2008), 15-40; A. Papaconstantinou, "They Shall Speak the Arabic Language and Take Pride in It: Reconsidering the Fate of Coptic after the Arab Conquest", Le Museon 120/3-4 (2007), 273-299; S. Rubenson, "Translating the Tradition: Some Remarks on the Arabization of the Patristic Heritage in Egypt", Medieval Encounters 2 (1996), 4-14. 
giderek Grekçe ve Ârâmîce'nin yerini alan önemli bir aracı olarak Arapçayı hevesli bir şekilde benimsemişlerdi bile. ${ }^{16}$ Doğu İslam dünyasındaki diğer Hristiyan gruplar aynı şekilde davrandılar ve dokuzuncu yüzyıla gelindiğinde artık Arap dilinde başarılı ve çeşitlilik sahibi bir Hıristiyan teolojik literatürüne sahiptik.

Dördüncü olarak, Araplaşmaya çok daha yavaş fakat kalıcı bir İslamlaşma süreci eşlik etti. Sosyal ve ekonomik faktörler özellikle Abbasi döneminin başlangıcından (750) itibaren Hiristiyanların yeni dine girmesine sebep oldu. İslam'a girmek onları cizye ödemekten muaf tuttu ve sosyal durumlarını yükseltti. ${ }^{17}$ İslam'dan dönmek Müslüman hukukunda ölümle cezalandırılırdı ve bu doğrultuda biz birkaç Hıristiyan'ın İslam'a girip sonra yeniden Hıristiyanlığa döndüğünü ve Müslüman yetkililer tarafından şehit edildiğini bilmekteyiz. ${ }^{18} \mathrm{Bu}$ tarz şehitlik öyküleri Hıristiyan yetkililerce ilk etapta kendi cemaatlerini İslam'a girmekten vazgeçirmek için önemli bir vasıta olarak kullanıldı.

$\mathrm{Bu}$ nedenle erken İslamî dönemde Hıristiyanların ilk olarak; fetihlerin dünyanın sonunun çok yakın olduğunun bir işareti ve günahlarına karşılık ilahi bir ceza olarak gören apokaliptik eserler yazarak, İslam fetihlerine karşılık vermeleri şaşırtıcı değildir. ${ }^{19}$ Ancak dünyanın sonunun gelmediği ve Müslüman yönetimin kalıcı olduğu anlaşıldıkça Hıristiyanlar, yeni realiteye hatırı sayılır bir ustalıkla adapte oldular. Hiristiyanların, Müslümanların, Yahudilerin ve diğer dinî grupların yüzyıllar boyunca bir tür "çoğulcu denge" (plüralist equilibrium) (William Dalrymple'a ait bir terim, bazen "convivencia" olarak da adlandırılır) içinde varlıklarını beraberce sürdürdüklerini söylemek adilâne olur. Bu ortamda Hıristiyanlar, önemli ölçüdeki toplumsal baskılara rağmen dinî bir topluluk olarak tutunabilmişlerdir. Dinler arası statüko genel olarak korundu, fakat Ortadoğu Hıristiyan topluluklarına dikkat çekici, kalıcı zararlar veren ve aşamalı olarak düşüşlerine sebep olan ciddi bozulmalar da vard1.

16 S. Griffith, Arabic Christianity in the Monasteries of Ninth-Century Palestine (Aldershot: Ashgate, 1992); S. Griffith, The Beginnings of Christian Theology in Arabic: Muslim-Christian Encounters in the Early Islamic Period (Aldershot: Ashgate, 2002); Griffith, The Church in the Shadow of the Mosque, 45-74; M. Levy-Rubin, "Arabization and Islamization in the Palestinian Melkite Community during the Early Muslim Period", Sharing the Sacred, ed. A. Kofsky-G. G. Stroumsa (Jerusalem: Yad Izhak Ben Zvi, 1998), 149-162; K. Leeming, "The Adoption of Arabic as a Liturgical Language by the Palestinian Melkites", ARAM 15 (2003), 239-246; D. J. Wasserstein, "Why Did Arabic Succeed Where Greek Failed? Language Change in the Near East after Muhammad", Scripta Classica Israelica 22 (2003), 257-272.

17 Griffith, The Church in the Shadow of the Mosque, 34-35, Zuqnin Kroniği bağlamında; S. Griffith, "Syriac Writers on Muslims and the Religious Challenge of Islam", SEERI 7 (Kottayam, 1995), 6.

18 Griffith, The Church in the Shadow of the Mosque, 147-153; R. Hoyland, Seeing Islam as Others Saw It: A Survey and Evaluation of Christian, Jewish and Zoroastrian Writings on Early Islam (Princeton: NJ: Darwin Press, 1997), 336-386.

19 Griffith, The Church in the Shadow of the Mosque, 23-35. 


\subsection{On Dokuzuncu Yüzyıla Kadar Hiristiyan Araplar}

Emevîler dönemi boyunca halifeler yeni fethedilen bölgelerde İslam adına kamusallaştırmaya yönelik ilk girişimlerini yapıyorlardı. Abdülmelik döneminde (685-705) Kudüs'teki Kubbetü's-Sahra ve oğlu Velîd döneminde (705-715) Şam'daki Emevî Camisi'nin inşasında bu açıkça görülmektedir. Bunların ilki Harem-i Şerif üzerinde şehirdeki Hıristiyan kiliseler ile rekabet etmesi için inşa edilmiş, teslis ve enkarnasyon gibi Hıristiyan inançlarını eleştiren Kuran ayetleri ile bezenmişti. ${ }^{20}$ İkincisi ise Kadıköy yanlılarından alınan Vaftizci Yahya Kilisesi'nin yerine inşa edilmişti. 721 yılında halife 2. Yezid (720-724) kamuya açık alanlarda haç ve ikonların teşhir edilmesini yasaklayan ve onların imha edilmesini emreden kısa ömürlü bir ferman yayımladı. Bu durum halifeliğe bağlı bulunan Hıristiyan nüfusu etkilerken aynı şekilde Bizans'taki ikonoklast hareketin başlamasına etki etmiş olabilir. ${ }^{21}$ Bununla birlikte Hıristiyanlar toplumdaki imtiyazlı pozisyonlarını korudular; zira bu devlet memurlukları ve idari görevler açısından kaçınılmaz bir durumdu.

Abbasiler devrinde, Şam'da olan halifelik merkezi yeni kurulan başkent Bağdat'a taşındı. Bu değişim geleneksel olarak Irak merkezli olan Doğu Kilisesi için yararlı olurken, özellikle idari işlerdeki hizmetleri Emevîler tarafından hevesle aranan Kadıköy yanlıları gibi Hiristiyan gruplar için pahalıya mal oldu. Doğu Kilisesi Katolikos'u I. Timothy (780-823), Abbasi sarayına daha yakın olmak için patriyarklık merkezini eski Sâsâni başkenti Selevkiya Tizpon'dan (Seleucia-Ctesiphon) Bağdat'a taşıdı. Bu dönem boyunca Hiristiyanlar, devlet memuru, hekim ve daha önemli ölçüde felsefî, bilimsel ve tıbbî çalışmaları Grekçe ve Süryaniceden Arapçaya aktaran tercümanlar olarak yeni gelişen İslam toplumuna önemli katkılar sundular. ${ }^{22}$

Bizans'ın 969'da Antakya ve civarını geri alması o bölgedeki Arap Ortodoks toplumu açısından çok önemli bir dönem başlattı. ${ }^{23}$ Açıklığa kavuşturmak için şunu not etmek gerekir

20 O. Grabar, The Dome of the Rock (Cambridge: MA: Belknap Press, 2006); A. Kaplony, The Haram of Jerusalem, 324-1099 (Stuttgart: Franz Steiner, 2002)

21 S. Griffith, "Christians, Muslims and the Image of the One God: Iconophilia and Iconophobia in the World of Islam in Umayyad and Early Abbasid Times", Die Welt der Gotterbilder, ed. B. Groneberg-H. Spieckermann (Berlin and New York: Walter de Gruyter, 2007), 347-380.

22 D. Gutas, Greek Thought, Arabic Culture: The Graeco-Arabic Translation Movement in Baghdad and Early “Abbasid Society (2nd-4th/5th-10th centuries) (London: Routledge, 1998); Griffith, The Church in the Shadow of the Mosque, 106-28.

${ }^{23}$ K. Ciggaar-M. Metcalf, East and West in the Medieval Eastern Mediterranean, I: Antioch from the Byzantine Reconquest until the End of the Crusader Principality (Leuven: Peeters, 2006); H. Kennedy, "Antioch: From Byzantium to Islam and Back Again", The Byzantine and Early Islamic Near East, Essay VII (Aldershot: Ashgate, 2006); K. P. Todt, "Notitia und Diozesen des griechisch-orthodoxen Patriarchates von Antiocheia im 10. und 11. Jh.", Orthodoxes Forum 9 (1995), 173-185; K. P. Todt, "Region und griechisch-orthodoxes 
ki "Arap Ortodoks" ile Arapça konuşup Bizans ayinlerini yapan Ortodoks Hiristiyanlar kastedilmekte olup (Arapçada, "Rum” (Bizans) Ortodoks) bunlar geleneksel olarak Melkitler olarak adlandırılmaktadır. ${ }^{24}$ Fakat günümüzde Melkit terimi Bizans ayinlerini uygulayan Doğu Katolik Kilisesi için kullanılmaktadır. İngilizcede Arap Ortodoks ifadesi yanlışlıkla ya “Grek" Ortodoks (ne etnik olarak Grek ne de zorunlu olarak Grekçe eğitilmiş olmalarına rağmen) ya da "Antakya" Ortodoks (hepsi değilse de çoğunun bağlı olduğu Antakya Patrikliğine referansla) olarak isimlendirilmektedir. Arap Ortodokslar Bizans ile yeniden birleşmek için kendi patristik miraslarını Arapçaya çevirmek üzere büyük bir girişim başlattı. Bu çeviriler daha sonra bütün toplumlar içindeki Hıristiyanlar, özellikle Kıptîler tarafından kullanıldı hatta sonraları onlardan bazıları Etiyopyacaya çevrildi.

Bizans'ın Antakya'yı geri alması Fatımîlerin Filistin'i ele geçirmesi ile aynı zamana denk geldi. Fatımî yönetimi Mısır ve Suriye'deki Hıristiyanlara ve genel olarak azınlıklara karşı (yukarıda da bahsedilmiş olan Halife Hâkim dönemi istisna) hoşgörülüydü. Mental olarak dengesiz olan bu hükümdar iktidara gelince Mısırlı Hıristiyanlara (hem Kıptî hem de Arap Ortodokslara) ve Yahudilere karşı ağır işkenceler başlattı. Onun politikaları Filistin Hristiyanlarını da etkiledi ve o 1009 yılında Kudüs'teki Kıyamet Kilisesi'nin (Holy Sepulcher) yıkılmasını (daha sonraları Bizans desteği ile yeniden inşa edildi) emretti. Bazı diğer kiliseler de ya yıkıldı ya da camiye dönüştürüldü. Bu dönemde Mısır ve Filistinli pek çok Hıristiyan (kroniği bu olaylar hakkındaki ana kaynaklardan biri olan ünlü tarihçi Yahya el-Antakî dâhil) Bizans yönetimindeki Antakya'ya kaçtı.

Haçlı seferleri sırasında, muhtemelen Suriye ve Filistin'de hâlâ büyük çoğunluğu oluşturan Hıristiyanlara kuşku ve anlaşmazlıkla yaklaşıldı. Çünkü bu yerli Hıristiyanların sahip olduğu Arap ve Süryani kültürü, onları adeta Müslümanlardan ayırt edilemez hale getirmişti. Dahası, Latin kilisesinin bakış açısına göre heretik olmaları, her ne kadar Frenkler ile yerliler arasında bir çeşit ortak yaşam biçimi gelişmiş olsa da, onları Frenklere göre aşağı kılıyordu. ${ }^{25}$ Erken dönemde yerli Hıristiyanların başına gelenler Müslüman nüfusun başına

Patriarchat von Antiocheia in mittel- byzantinischer Zeit", Byzantinische Zeitschrift 94 (2001), 239-267; K. P. Todt, "Griechisch-Orthodoxe (Melkitische) Christen im zentralen und südlichen Syrien. . . (635-1365)", Le Muséon 119/1-2 (2006), 33-88; V. V. Krivov, "Arab-Christians in Antioch in the Tenth-Eleventh Centuries [in Russian]", Traditions and Heritage of the Christian East, ed. D. E. Afinogenov-A. M. Muraviev (Moscow: Indrik, 1996), 247-55.

24 S. Griffith, "The Church of Jerusalem and the "Melkites": The Making of an "Arab Orthodox" Christian Identity in the World of Islam, 750-1050", Christians and Christianity in the Holy Land, ed. O. Limor- G. G. Stroumsa (Turnhout: Brepols, 2006), 173-202.

25 J. Prawer, "Social Classes in the Crusader States: The "Minorities", A History of the Crusades, The Impact of the Crusades on the Near East, ed. N. P. Zacour-H. W. Hazard (Madison: WI: University of Wisconsin Press, 
gelenlerden daha iyi değildi. Örneğin 1098 yılında Antakya'nın kuşatılması sırasında haçlılar hem Müslümanları hem de Hıristiyanları ayrım gözetmeden katlettiler. ${ }^{26}$ Haçlılar daha sonra Süryani Ortodoks ve Ermenilere, Bizans'a sempati duyduklarından şüphelendikleri Grek ve Arap Ortodokslara davrandıklarından daha iyi muamelede bulundular. Öyle ki Süryani Ortodokslar tarihte ilk defa Kudüs'teki Kıyamet Kilisesi içerisinde kendi şapellerine sahip oldular. ${ }^{27}$ Aynı şekilde haçlıların yönetimi altında Lübnan Dağı'ndaki Marûnîler 1182 yılında resmen Roma ile birleştiler.

Hıristiyanlar, Selçuklular ve Eyyûbilerin yönetimi altında nispeten güvendeydiler ve Moğolların yönetimi altında kısa süreli bir rönesansın tadını çıkardılar. ${ }^{28}$ Moğollar 1258 yılında Bağdat'1 yıktı ve Abbasi hilafetini devirip, on binlerce insanı öldürdüler. Fakat Moğol hükümdarı Hülâgü (1256-1265), Hıristiyan olan karısının şefaati sayesinde Hıristiyanları öldürmekten kaçındı. Moğol hükümdarlar başlangıçta Hıristiyanlara karşı hoşgörülü davranmış, cizyeyi kaldırmış, kiliselerin onarılmasına müsaade etmişlerdi ve Hıristiyanlığa geçmeyi düşünüyorlardı. (Bazı Moğol kabileler; Uygurlar, Naymanlar ve Keraitler zaten Nestûri Hıristiyan idiler.) Bu gerçekleşmeyip Hıristiyanlık yerine İslam'a girdiklerinde; Irak'taki Hıristiyanlar, Müslüman çoğunluk tarafından Moğolların imtiyazlıları ve müttefikleri olarak düşünüldüğünden kanlı bir misillemeyle karşı karşıya kaldılar.

1260 yılında Filistin'deki Ayn Calut'ta Moğollara karşı kesin bir zafer kazanan Memlükler sekiz yıl sonra Antakya'yı kuşatıp; Frenkler'den aldılar. Bu esnada Hıristiyan halkı öldürdüler ve köleleştirdiler, kiliseleri ve civardaki manastırları (Ünlü, Mucize Sahibi Aziz Simon Manastırı dâhil) yıktılar. ${ }^{29}$ Bu yıkımla harap olan Antakya Patrikliği'nin yüz yıl daha kalıcı bir merkezi olmadı; ancak; 1365'te Şam'da kalıcı olarak yeniden kuruldu ve günümüze kadar geldi. ${ }^{30}$

1985), 5/59-115; C. MacEvitt, The Crusades and the Christian World of the East: Rough Tolerance (Philadelphia: University of Pennsylvania Press, 2007)

26 Ciggaar-Metcalf, East and West in the Medieval Eastern Mediterranean, 247.

27 Prawer, "Social Classes in the Crusader States: The "Minorities.", 76; MacEvitt, The Crusades and the Christian World of the East, 169.

28 J. M. Fiey, Chrétiens syriaques sous les Mongols (Il-Khanat de Perse, XIIIe- XIVe s.) (Leuven: Secrétariat du Corpus SCO, 1975)

29 J. Nasrallah, Histoire du mouvement littéraire dans l'Église melchite du Ve au XXe siècle (Leuven: Peeters, 1983-1989), 3/63-65; J. Nasrallah, “Couvents de la Syrie du Nord portant le nom de Siméon”, Syria 49 (1972), 127-159; W. Djobadze, Archaeological Investigations in the Region West of Antioch on-the-Orontes (Stuttgart: Franz Steiner, 1986), 57-115; D. W. Morray, "The Defences of the Monastery of St Simeon the Younger on Samandag", Orientalia Christiana Periodica 60 (1994), 619-623.

30 Todt, "Griechisch-Orthodoxe", 85-87; D. Korobeinikov, "Orthodox Communities in Eastern Anatolia in the Thirteenth and Fourteenth Centuries, Part I", Al-Masaq 15/2 (2003), 197-214; D. Korobeinikov, "Orthodox 
14. ve 15. yüzyıl Orta Doğu'da Hıristiyanlığın keskin bir düşüş yaşadığı ve Müslümanların Hıristiyanlara karşı hoşgörüsüzlükte zirveye çıktığı, Müslüman teolog İbn Teymiyye'nin (ö. 1328) Hıristiyanlık karşıtı çalışmaları ile temsil edilen bir dönemdi. ${ }^{31}$ Orta Doğu'daki Hıristiyan topluluklar yaklaşık 1347 yılında İslam toplumuna ulaşan ve tahmini olarak Misır ve Suriye nüfusunun tamamının üçte biri ila dörtte birinin yaşamını sonlandıran veba salgını ile daha fazla harap oldu. ${ }^{32}$ Timur'un (ö. 1405) acımasız askeri harekâtları Irak'taki Hıristiyan nüfusu kırıp geçirdi ve Doğu Kilisesi'ne yeniden kendisini toparlayamayacağı bir darbe indirdi.

Osmanlı döneminde 16. yüzyıldan başlayarak Doğu Akdeniz'deki Hıristiyan Arap topluluklar yavaş bir iyileşme gösterdi ve canlanma yaşadı. ${ }^{33}$ Diğerlerinin yanı sıra bu durum, çok az el yazmasının kopya edildiği yaklaşık üç asırlık bir boşluktan sonra 17. yüzyıla ait bir dizi Hıristiyan Arapça elyazması ile kanıtlanmıştır. Bu ayrıca Doğu Akdeniz' deki Hıristiyan nüfusun istikrarlı şekilde arttı̆̆ı bir döneme denk gelir. ${ }^{34}$

16. yüzyıldan 18. yüzyıla dek Batılı misyonerlerin Orta Doğu'daki bazı Hıristiyanları Roma ile birleştirme çabaları başarılı oldu ve Doğu Katolik kilisesi şeklinde adlandırılan birtakım kiliseler kuruldu. Bu Orta Doğu'daki Hıristiyan toplulukların ikiye bölünmesine etki edip istenmeyen bir bölünmeye sebep oldu. Onlardan bazıları Roma ile birleşmek istedi, bazıları ise bunu yapmaktan kaçındılar. Doğulu Katolikler tipik olarak kendilerini Doğu ve Batı Hıristiyanları arasında bir köprü olarak görmekte ve Ekümenik harekette aktif olma eğilimindedirler. Onlar sık sık kendi Ortodoks kardeşleri tarafından geleneklerini terk ettikleri noktasında eleştirilmekte ve "ana kiliseye" dönmeleri istenmektedir.

Osmanlı döneminde imparatorluktaki tüm Kadıköy yanlısı Hıristiyanların, İstanbul Patrikliği'ne bağlı tek bir dinî toplum (millet) olarak yeniden organize edilmesi diğer patriklikleri etkiledi; litürjik pratikleri İstanbul ile aynı çizgiye getirildi ve Grek din adamları tarafından yönetildiler. Antakya Patrikliği Rus İmparatorluğunun yoğun diplomatik desteği

Communities in Eastern Anatolia in the Thirteenth and Fourteenth Centuries, Part II", Al-Masaq 17/1 (2005), $1-29$.

31 T. F. Michel, A Muslim Theologian's Response to Christianity: IbnTaymiyya's al-Jawab al-Sahih (Delmar: NY: Caravan Books, 1984)

32 B. Shoshan, "Waba [Plague]", Encyclopaedia of Islam (Leiden: Brill, 2000-2002), 11/2-3.

33 V.V. Polosin vd., The Arabic Psalter: A Supplement to the Facsimile Edition of Manuscript A187 "The Petersburg Arabic Illuminated Psalter" (St Petersburg: Kvarta, 2005); K. A. Panchenko, Blizhnevostochnoe Pravoslavie pod osmanskim vladychestvom: Pervye tri stoletija (1516-1831) (Moscow: Indrik, 2012)

34 Y. Courbage-P. Fargues, Christians and Jews under Islam (London and New York: I. B. Tauris, 1997), 57-90; önemli istatistiklerle beraber. 
sonucu 1899'da Arap Ortodokslar tarafından devralınırken Kudüs ve İskenderiye Patriklikleri günümüze kadar etnik olarak Grek hiyerarşisi tarafından yönetilmiştir. ${ }^{35}$

\subsection{Yirminci Yüzyılda ve Yirmi Birinci Yüzyılın Başlarında Hristiyan Araplar}

Birinci Dünya Savaşı esnasında ve hemen sonrasında Hıristiyan Arapların yaşadığı bölgeler, Anadolu ve Doğu Trakya'daki Hıristiyanların maruz kaldığı Ermeni soykırımı, "Süryani" Sayfosu (soykırım ya da katliam) ve Yunan “Küçük Asya Felaketi” olarak bilinen sistematik sürgün ve soykırımlardan önemli ölçüde etkilenmemiştir. Hıristiyan Araplar özellikle Lübnanlı ve Filistinliler 19. ve 20. yüzyılın sonlarında Arap edebiyatı, Arap ulusalcılığı ve siyasi canlanma noktalarında önde gelen kişiler oldular. Önemli edebî şahsiyetler arasında Arapça tarihi roman yazarlığının kurucusu Corcî Zeydan (1861-1914, Arap Ortodoks), İlyada'yı Arapçaya çeviren Süleyman Bustânî (1856-1925, Marûnî), Lübnan asıllı Amerikalı yazar Cibran Halil Cibran (1883-1931, Marûnî), Lübnanlı yazar Mikail Naimi (1889-1988, Arap Ortodoks), Kudüslü eğitimci ve yazar Halil Sakakinî (1878-1953, Arap Ortodoks), Filistinli roman yazarı Emile Habibi (1922-96, Protestan) ve çağdaş Lübnanlı yazar Elias Khoury (d. 1948, Arap Ortodoks) bulunmaktadır. Lübnanlı ünlü şarkıcı Feyrûz (Nouhad Haddad, d.1935) da Arap bir Hıristiyan'dır; Süryani Katolik bir ailede doğmuş fakat Arap Ortodoksluğuna geçmiştir. Arap siyasetçiler içinde Baas Partisi'nin kurucusu Mişel Eflak (1910-1989), Filistin Halk Kurtuluş Cephesi kurucusu Corc Habaş (1926-2008) ve Arap milliyetçisi düşünür Konstantin Züreyk'ten (1909-2000) bahsetmek mümkündür. Onların tamamı ideolojik olarak Marksist olsalar da Arap Ortodoks toplumuna mensuplardı. Filistinli entelektüel ve siyasetçiler arasında Edward Said, Hanan Aşravi, Afif Safieh ve Azmî Bişare gibi kayda değer sayıda Hıristiyan vardı. Müslüman hemşehrileri gibi Filistinli Hıristiyanlar da 1948 Filistin Göçü'nden (Nakba) ve sonraki olaylardan ağır bir şekilde etkilenmiş ve çoğu sürgüne zorlanmıştı.

Diğer çatışmalar da (özellikle 1860'taki Hıristiyan karşıtı katliamlar, Lübnan iç savaşı (1975-90), ABD’nin Irak işgali (2003) ve Suriye'de şiddetlenen iç savaş) Arap Hıristiyan nüfusu üzerinde ağır travmalar yaşattı. Bu çatışmaların kurbanları (örneğin 1860'da şehit edilen Şamlı Aziz Joseph ve Suriye'de 2012'de Ocak ve Ekim'de sırayla öldürülen Ortodoks papazlar Basilios Nassar ve Fadi Haddad) şehit olarak tazim edilirler.

35 M. I. Yakushev, "On the Restoration of the Rule of Arab Patriarchs in the Patriarchate of Antioch [in Russian]", Lomonosovskie Chtenija, Vostokovedenie (Moscow: Akademija Gumanitarnykh Issledovanij, 2006), 374-379. 
Antakya Ortodoks Patrikliği 1942'de George Khodr (Lübnan Dağı Metropoliti) ve diğerleri tarafından Ortodoks Gençlik Hareketi'nin kurulmasıyla yirminci yüzyılın ortasında manevi bir yenilenme yaşadı. ${ }^{36} \mathrm{Bu}$ yenilenmenin bir parçası olarak Aziz George Manastırı (Deyru'l-Harf) yeniden açıldı, ${ }^{37}$ Lübnan'da Ortodoks Balaman Üniversitesi kuruldu, Grek kilise babalarının bir dizi çalışmaları yeniden Arapçaya tercüme edildi, Arap Ortodoksluğu ve özellikle Başrahip Tuma Bitar'ın (1995) "Antakya Geleneğinde Unutulan Azizler" isimli kayda değer monografisi dâhil Antakya Ortodoks Patrikliğine dair birtakım orijinal çalışmalar Arapça olarak ortaya kondu. Eş zamanlı olarak Natrun Vadisi'ndeki Aziz Macarius Manastırı'nda bir keşiş olan Matta el-Miskîn (veya Miskin Matta, 1919-2006) Kıptî Kilisesi'nde benzer bir manevî canlanmaya öncülük etti. ${ }^{38}$ Marûnîler arasında da münzevî bir canlanmanın belirtileri hissedildi. ${ }^{39}$

Yirminci yüzyılda ve yirmi birinci yüzyılın başlarında, esas olarak göç yoluyla ve Müslümanlar arasındaki kayda değer yüksek doğum oranı (bu eşitsizlik nispeten yeni bir olgudur) nedeniyle Orta Doğu nüfusu içindeki Hıristiyan Arapların yüzdesi büyük ölçüde azaldı. Buna karşın rakamsal olarak nüfusları artmış olabilir. Her inançtan Hıristiyan Arap göçmen toplulukları günümüzde Kuzey ve Güney Amerika, Avrupa ve Avustralya'nın her tarafında bulunmaktadır. Bu topluluklar asıl ülkeleriyle yakın ilişkilerini sürdürmektedirler.

\section{Hıristiyan Arap Literatürü: Genel Bir Bakış}

\subsection{Grekçe ve Diğer Dillerden Çeviriler}

Daha önce bahsi geçen, Grekçe felsefî, bilimsel ve tıbbî eserlerin tercüme edildiği; çok daha iyi bilinen Grekçe-Arapça çeviri hareketine ek olarak sekizinci yüzyıldan itibaren, çoğu erken Hıristiyanlık literatüründen olan Eski ve Yeni Ahit, apokrif İnciller, azizlerin yaşantıları, vaazlar, litürjik metinler ve patristik çalışmalar çoğunlukla Grekçe, Süryanice ve Kıptîceden Arapçaya çevrildi.

36 G. N. Nahas, “Le mouvement de la jeunesse Orthodoxe”, Proche-Orient Chretien 43 (1993), 69-81.

37 H. Kassatly, La communauté monastique de Deir el Harf (Balamand-Lebanon: Universite de Balamand, 1996)

38 Matthew the Poor, Orthodox Prayer Life: The Interior Way ( Crestwood: NY: St Vladimir's Seminary Press, 1983); Matthew the Poor, Communion of Love (Crestwood: NY: St Vladimir's Seminary Press, 1984); U. Zanetti, "Tradition et modernité dans l'Église copte", Traditions and Heritage of the Christian East, ed. D. E. Afinogenov-A. M. Muraviev (Moscow: Indrik, 1996), 221-238; A. O’Mahony, “Coptic Christianity in Modern Egypt", The Cambridge History of Christianity, Eastern Christianity, ed. M. Angold (Cambridge: Cambridge University Press, 2006), 5/488-510.

39 G. G. Hourani-A. B. Habachi, “The Maronite Eremitical Tradition: A Contemporary Revival”, Heythrop Journal 45 (2004), 451-465. 
Hıristiyan literatürünün Arapçaya çevrilmesi ilk olarak Kadıköy yanlısı Filistin manastırlarında, özellikle de dokuzuncu yüzyılda çok dilli bir keşiş topluluğunun Grekçe, Süryanice, Arapça ve Gürcüce çeviriler yaptığı Mar Saba Manastırı'nda meydana geldi. Bu toplulukta Süryani İshak'ın bazı eserleri neredeyse aynı anda Süryanice orijinalinden Grekçe, Gürcüce ve Arapçaya çevrildi. ${ }^{40}$ Çeviriler daha sonra, Bizans'ın şehri geri almasının ardından Antakya bölgesinde yapılıyordu. ${ }^{41}$ Arap Ortodoks diyakoz Abdullah b. el-Fadl (etkin yılları 1050 civarı) belki de patristik çalışmaların en üretken çevirmenidir. Altınağızlı Yuhanna (John Chrysostom), Basil, Nissalı Gregory, Maksimus, Pseudo-Caesarius, Yuhanna ed-Dımeşkî, Giritli Andrew ve Süryani İshak'ın çalışmalarını Arapçaya çevirmiştir. Ek olarak onun Arapça Mezmurlar çevirisi Hıristiyan Arap dünyasında bugüne kadar en etkili çeviri oldu. ${ }^{42}$ Çeviri faaliyeti on birinci yüzyılda komşu Şam’a yayıldı. Orada, Arap Ortodoks çevirmen İbn Sahkûk, Corpus Dionysianum'un tam bir Arapça versiyonunu yapmasiyla biliniyordu. ${ }^{43}$

Grekçe aslı kayıp fakat Arapçası korunan patristik literatür başyapıtlarından biri de (ne yazık ki henüz basılmadı) büyüleyici metin Noetic Paradise'tır. ${ }^{44}$ Aslen yedinci veya sekizinci yüzyılda Grekçe olarak yazılmış olan Noetic Paradise cennetten düşüş hikâyesine dayanır. Eserin başlığında sözü edilen "cennet" düşüşten sonra insan aklının (nous) dışarı atıldığı melekût âlemidir. Metin, erdemler ve kötülükler üzerine; bir kimsenin aklının arındırılıp tekrardan akıl cennetine kabul edilmesi için başka bir kimsenin onun kalp toprağını nasıl "sürmesi" gerektiğini açıkladığı ve erdemleri yetiştirip kötülüklerle savaştığı bir analize girişir. ${ }^{45}$

\subsection{Teoloji ve Dinî Polemik}

Yukarıda açıklandığı üzere, sekizinci yüzyılda Filistin'deki Kadıköy yanlılarına ait manastırlarda Arapça konuşan keşişler Hıristiyan teolojisini açıklamak için Arapçayı bir araç olarak kullanan ilk kişilerdi. Arapça onuncu yüzyılda tüm Hıristiyan mezhepler tarafından

40 Brock, "From Qatar to Tokyo", 475-84; Brock, "Syriac Authors", 85-96.

41 Nasrallah, "Histoire du mouvement", 3/196-220, 273-310, 387-91.

42 Polosin vd., The Arabic Psalter, 2005.

43 A. Treiger, "New Evidence on the Arabic Versions of the Corpus Dionysiacum", Le Museon 118 (2005), 219 240; A. Treiger, "The Arabic Version of Pseudo-Dionysius the Areopagite's Mystical Theology, Chapter 1", Le Museon 120 (2007), 365-93.

44 S. Noble-A. Treiger, The Orthodox Church in the Arab World (700-1700): An Anthology of Sources (DeKalb: Northern Illinois University Press, 2014), 8. bölüm.

45 Samuel Noble ve şuanki yazar Arapçadan çevrilen on iki Ortodoks metinden oluşan bir antolojinin editörlüğünü yapıyor: The Orthodox Church in the Arab World (700-1700). Bu kitap Noetic Paradise'den yapılan alıntıların ilk İngilizce çevirisini içeriyor. 
kullanıldı. En erken tarihli çalışmalar genel olarak anonimdir ve ismini bildiğimiz Arapça yazan en eski (dokuzuncu yüzyıl) üç teolog Theodore Ebu Kurra (Arap Ortodoks), ${ }^{46}$ Ebu Râita et-Tikritî (Süryani Ortodoks), ${ }^{47}$ ve Ammar el-Basrî́dir (Nestûri).. ${ }^{48}$ Yuhanna edDımeşkî’nin izinden giden Theodore Ebu Kurra, Müslüman baskısı altında, Hıristiyanların, Mesih'in mucizevi resmine (kutsal mendil; en azından Eusebius'a kadar giden bir kilise geleneğine göre el ile yapılmayıp (acheiropoieton), Mesîh tarafından Urfa kralı Abgar'a gönderilen ve kendisiyle iyileştiği kabul edilen resim) saygı göstermekte isteksiz davrandıkları Urfa'daki sosyal duruma bir tepki olarak ikonları savunan Arapça bir eser yazd $1 .{ }^{49}$

Arap Hıristiyanlar teslise dair teolojilerini açıklamak için sıklıkla teslisin hipostazlarını tek bir ilahî özün "öz sıfatları” olarak takdim ettiler. Tartışılabilir olmasına rağmen bu teoloji yine de Hıristiyan çevrelerde popüler oldu. Bu, Müslümanların triteizm olarak değerlendirip eleştirdikleri geleneksel teslis teolojisinden daha az etkilenmekteydi. Zira hipostazlar "öz sıfatlar" olarak yeniden tanımlandığında, Hıristiyan Arap teologlar Müslümanların da tanrının sıfatlarını kabul ettikleri gerçeğine her zaman başvurabilirlerdi..$^{50}$ Özel bir tür de Kıptî-Arap literatürünün “Altın Çağ1” olan 13. yüzyılda, özellikle Kıptî-Arap teologlar arasında popüler olan Hıristiyan teolojik ansiklopedileri ile ortaya kondu. el-Mu'temen b. el-Assal'in "Dini Illkeler Toplamı" (Summa of the Principles of Religion) (yaklaşık 1263) başlığını taşıyan yetmiş bölümlük ansiklopedisi bu türün en ünlü örneğidir. ${ }^{11}$ İbnü'l-Assal, Arapça tercümelerine ulaşabildiği çeşitli Grekçe kaynaklardan (hem felsefî hem patristik), Hıristiyan Arap yazarlardan hatta Müslüman ve Yahudi teologlardan (Örneğin, Fahreddin Razî ve Maymonides) yararlanmaktadır.

46 J. C. Lamoreaux, Theodore Abu Qurrah (Provo: UT: Brigham Young University Press, 2005)

47 S.T. Keating, Defending the "People of Truth" in the Early Islamic Period: The Christian Apologies of Abu Ra'itah (Leiden: Brill, 2006)

48 S. Griffith, "Ammar al-Basri's Kitab al-burhan: Christian Kalam in the First Abbasid Century", Le Museon 96 (1983), 145-181; M. Beaumont, "Ammar al-Basri on the Incarnation", Christians at the Heart of Islamic Rule: Church Life and Scholarship in "Abbasid Iraq", ed. D. Thomas (Leiden: Brill, 2003), 55-63.

49 S. Griffith, A Treatise on the Veneration of the Holy Icons. . . by Theodore Abu Qurrah (Leuven: Peeters, 1997)

50 R. Haddad, La Trinité divine chez les théologiens arabes, 750-1050 (Paris: Beauchesne, 1985); M. N. Swanson, “The Trinity in Christian-Muslim Conversation", Dialog 44/3 (2005), 256-263.

51 Al-Mu'taman ibn al-'Assal vd., Majmu' usul al-din [Summa dei principi della Religione] (Jerusalem: Franciscan Printing Press, 1998-2002) 6 cilt; W. Abullif, Dirasa 'an al-Mu'taman ibn al-'Assal wa-kitabihi "Majmu' usul al-din" wa-tahqiqihi (Jerusalem: Franciscan Printing Press, 1997); W. Abullif, "Les sources du Mağmu' usul al-din d'al-Mu'taman ibn al-'Assal", Parole de l'Orient 16 (1990-1991), 227-238; S. K. Samir, "Date de la composition de la "Somme theologique" d'al-Mu'taman b. al- Assal", Orientalia Christiana Periodica 50 (1984), 94-106. 
Teoloji polemikten ayrılamazdı; bu nedenle Arap Hıristiyan teologlar görüşlerini açıklarken kaçınılmaz olarak İslam'a, rakip Hıristiyan gruplara ve diğer dinlere karşı polemik yaptılar. Yine de özel olarak Hıristiyan-Müslüman polemiğiyle ilgili çok daha fazla sayıda eser vard1. ${ }^{52}$ Abbasiler döneminde dinler arası tartışmalar sıklıkla “oturumlar" (mecâlis) adı verilen özel toplantılarda ve dinleyicilerin önünde gerçekleşirdi. Müslüman bir yöneticinin Hıristiyan teologlara görüşlerini açıklaması ve Müslüman bir muhatabıyla, hatta bizzat yöneticinin kendisiyle tartışması için izin verdiği bu tarz birkaç tartışmanın kopyalarına sahibiz. ${ }^{53}$

12. yüzyılda Sayda'nın Arap Ortodoks Piskoposu Antakyalı Pavlus, "Müslüman Bir Arkadaşa Risale" (Letter to a Muslim Friend) başlı̆̆ını taşıyan etkili bir polemik eseri yazdı. Bu eserde o bizzat Kuran'ın kendisine dayanarak Müslümanlara yönelik Hıristiyanlığın doğruluğunu kanıtlamaya çalışır. ${ }^{54}$ Antakyalı Pavlus'un bu eserinin bilinmeyen Kıbrıslı Hıristiyan bir yazar tarafından yapılan uyarlamasına Dımaşkî̀ ${ }^{55}$ (ö.1327) ve İbn Teymiyye dâhil Müslüman teologlarca birkaç reddiye yazılmasına sebep oldu. ${ }^{56}$

\subsection{Felsefe ve Felsefî Teoloji}

Hıristiyanlar, Grekçe felsefî eserlerin Arapçaya çevrilmesinde yer almalarıyla beraber aynı zamanda bu dilde orijinal felsefî eserler yazan ilk kişiler arasındaydılar. Nitekim ünlü Nestûrî çevirmen Huneyn b. İshak (ö.873) antik filozoflar ve onların sözleri hakkındaki derlemeleriyle bilinir. ${ }^{57}$ Onun genç çağdaşı, Arap Ortodoks çevirmen Kustâ b. Lûkâ (ö.912) "Ruh ve Can Arasındaki Fark Hakkında" (On the Difference between Spirit and Soul) başlıklı önemli eseri dâhil bir dizi felsefî eser yazdı.

Belki de en çok bilinen Hıristiyan Arap filozof, ünlü Müslüman filozof Farabi'nin (ö.950) öğrencisi olan Miafizit Yahyâ b. Adî’dir (ö.974).58 Onun en orijinal teolojik

52 D. Thomas, B. Roggema -A. Mallett, Christian-Muslim Relations: A Bibliographical History (Leiden and Boston: Brill, 2009) 4 cilt, devam ediyor.

53 Griffith, The Church in the Shadow of the Mosque, 77-81; Szilágyi in Noble ve Treiger, The Orthodox Church, 3. bölüm.

54 Bu eser Griffith, Noble ve Treiger tarafından İngilizceye çevrilmiştir. Bk. The Orthodox Church, 10. bölüm.

55 Ebû Abdillâh Şemsüddîn Muhammed b. Ebî Tâlib el-Ensârî ed-Dımaşkī es-Sûfî (ö. 727/1327 [?]). (Ç.N.)

56 Griffith, The Church in the Shadow of the Mosque, 166-69; R. Y. Ebied-D. Thomas, Muslim-Christian Polemic during the Crusades: The Letter from the People of Cyprus and Ibn Abi Talib al-Dimashqi's Response (Leiden: Brill, 2005)

57 Griffith, The Church in the Shadow of the Mosque, 119-22; S. Griffith, "Hunayn ibn Ishaq and the Kitab adab al-Falasifah: The Pursuit of Wisdom and a Humane Polity in Early Abbasid Baghdad", Malphono w-Rabo dMalphone: Studies in Honor of Sebastian P. Brock, ed. G. Kiraz (Piscataway: NJ: Gorgias Press, 2008), 135-60.

58 G. Endress, The Works of Yahya ibn 'Adi: An Analytical Inventory (Wiesbaden, Reichert, 1977); S. Griffith, Yahya ibn 'Adi: The Reformation of Morals (Provo: UT: Brigham Young University Press, 2002); Griffith, The 
düşüncelerinden biri teslisin hipostazlarını "akıl", "akleden" ve "akledilen" olarak tanımlamasıdır. Bu da Aristo felsefesi açısından "gerçekte birbiriyle özdeş" olarak anlaşılmaktadır; Müslüman filozoflara karşı teslis doktrinini kabul edilebilir göstermeye yönelik ustaca fakat pek başarılı olmayan bir girişimdir. ${ }^{59}$

İskenderiye'deki Yeni Eflatuncu geleneğe bağlı olarak Porphyry'nin Îsâĝûcîsini ve Aristoteles'in Kategoriler'ini şerh eden Nestûrî İbnü't-Tayyib ${ }^{60}$ ile patristik eserleri Arapçaya çeviren kişi olarak yukarıda adı geçen Arap Ortodoks diyakoz Abdullah b. el-Fadl'dan da bahsetmek gerekir. Abdullah b. el-Fadl aynı zaman da çağdaş Süryani Ortodoks düşüncesi ve Nesturi teologlarıyla olduğu kadar yanı sıra İslam felsefesi ile de meşgul olan özgün bir filozof teologdu. ${ }^{61}$

\subsection{Diğer Türler: Kitab-1 Mukaddes Tefsirleri, Azizlerin Menkıbeleri, Tarih, Şiir ve Seyahatnameler}

Hemen yukarıda Porphyry ve Aristo'nun şârihi olarak ifade edilen İbnü't-Tayyib aynı zamanda Kitab-1 Mukaddes'in tamamı hakkında bir tefsir yazd1. "Hıristiyanlık Cenneti" (The Paradise of Christianity) başlığını taşıyan ve Georg Graf ${ }^{62}$ tarafından "Hıristiyan Arap literatüründeki en geniş tefsir koleksiyonu" olarak adlandırılan bu devasa eser, Tekvin'deki bir bölüm istisna edilirse henüz basılmamıştır. ${ }^{63}$ Kitab-1 Mukaddes tefsirleri özellikle Kıptîler arasında popülerdi. Nitekim Markus b. Kanber (ö.1208) Pentakok (Tora) üzerine, Sim’an b. Kalil (ö. 1206’dan sonra) Matta İncili ve Mezmurlar hakkında ve Bûlus el-Bûşî ile İbn Kâtip Kaysar (her ikisi de on üçüncü yüzyıl ortalarında yaşadı) Vahiy Kitabı hakkında (bu eser üzerine Arapça yazılan sadece iki tefsir var) tefsirler yazdılar. ${ }^{64}$

Church in the Shadow of the Mosque, 122-125; R. Wisnovsky, "New Philosophical Texts of Yahya ibn 'Adi: A Supplement to Endress' Analytical Inventory", Islamic Philosophy, Science, Culture, and Religion: Studies in Honor of Dimitri Gutas, ed. F. Opwis-D. Reisman (Leiden and Boston: Brill, 2001), 307-326.

59 A. Perier, Petits traités apologétiques de Yahya Ben 'Adi (Paris: J. Gabalda and P. Geuthner, 1920), 24-27.

60 K. Gyekye, Arabic Logic: Ibn al-Tayyib's Commentary on Porphyry's “Eisagoge” (Albany: NY: SUNY Press, 1979); C. Ferrari, Der Kategorien kommentar von Abu l-Farağ`Abdallah ibn at-Tayyib: Text und Untersuchungen (Leiden: Brill, 2006)

61 G. Graf, Geschichte der christlichen arabischen Literatur (Vatican: Biblioteca Apostolica Vaticana, 1944-1953), 2/52-64; Nasrallah, "Histoire du mouvement", 3/191-229; S. Noble-A. Treiger, "Christian Arabic Theology in Byzantine Antioch: 'Abdallah ibn al-Fadl al-Antaki and His Discourse on the Holy Trinity", Le Muséon 124 (2011), 371-417; Noble-Treiger, The Orthodox Church, 7. bölüm.

62 Graf, Geschichte, 2/162.

63 J. C. J. Sanders, "Ibn al-Tayyib: Commentaire sur la Génèse”, Corpus Scriptorum Christianorum Orientalium, 274-75; Scriptores Arabici, 24-25; Secrétariat du Corpus SCO (Leuven, 1967)

64 Graf, Geschichte, 2/329-332, 337-338, 358-359, 380-384, sirasiyla; S. J. Davis, "Introducing an Arabic Commentary on the Apocalypse: Ibn Katib Qaysar on Revelation", Harvard Theological Review 101 (2008), 77-96. 
Azizlerin hayatlarına dair Arapça yazılan eserler arasında, Antakya yakınlarında Kadıköy yanlılarına ait Mucize Sahibi Aziz Simon Manastırı'nda bir keşiş olan Mikail elSim'anî’nin ( ö. Muhtemelen 1090) yazdığ1 Yuhanna ed-Dımeşkî'nin hayatından bahsetmek gerekir. ${ }^{65}$ Ayrıca erken İslamî dönemden itibaren birkaç Hıristiyan azizin (şehitler dâhil) hayatına dair Arapça yazılmış bir dizi esere sahip olduğumuz için şanslıyız. ${ }^{66}$

Hıristiyan Araplar tarihsel eserler yazmada üstün bir seviyeye çıktılar. ${ }^{67}$ Arap Ortodoks olan İskenderiye Patriği Eutychius (Said b. el-Bitrik, ö. 940) 938 yılına kadar gelen bir dünya tarihi yazdı. Onun tarihi, yukarıda bahsi geçen Yahya el-Antakî tarafından sürdürüldü. Onuncu yüzyılda Kuzey Suriye'deki Münbiç'in Arap Ortodoks Piskoposu Agapius (Mahbub) da dünyanın yaratılışından kendi zamanına kadar gelen bir dünya tarihi yazd1. ${ }^{68}$ Öncelikli olarak Süryanice yazmakla beraber, çok yönlü Süryani Ortodoks âlimi BarHebraeus (İbnü'l-İbrî, ö.1286) "Hanedanlıkların Kısa Bir Tarihi" (A Short History of the Dynasties) adı verilen Arapça bir kronik derledi. Kıptîler arasından ise Severus İbnü'lMukaffa'nın (onuncu yüzyıl) "İskenderiye Patrikleri Tarihi" (History of the Patriarchs of Alexandria) ve Mekîn'in (öl. 1273) dünya tarihine sahibiz. Daha sonraki yazarlar arasından genel bir Suriye tarihi ve Marûnîler hakkında ayrı bir tarihi yazan Marûnî Patrik İstifan edDüveyhî’den ${ }^{69}$ (öl. 1704) ve Arap Ortodoks tarihçi Mikail Berîkî’den (öl. 1782'den sonra) bahsedilebilir. ${ }^{70}$

İslam öncesi ve Emevîler dönemi Hıristiyan Arap şairleri (örneğin sırasıyla Adî b. Zeyd ve Ahtal) Arap edebiyatı öğrencileri tarafından çok iyi bilinmektedir. ${ }^{71}$ Daha az bilineni

65 R. D. Portillo, "The Arabic Life of St. John of Damascus", Parole de l'Orient 21 (1996), 157-88; S. Griffith, "Melkites," "Jacobites" and the Christological Controversies in Arabic in Third/Ninth-Century Syria", Syrian Christians under Islam: The First Thousand Years, ed. D. Thomas (Leiden: Brill, 2001), 20-42, referanslarla beraber.

66 B. Pirone, Leonzio di Damasco: Vita di Santo Stefano Sabaita (725-794) (Jerusalem: Franciscan Printing Press, 1991); J. C. Lamoreaux-C. Cairala, “The Life of Timothy of Kakhushta”, Patrologia Orientalis 48/4 (2001); Griffith, The Church in the Shadow of the Mosque, 150-166, daha fazla referansla beraber; Lamoreaux in Noble-Treiger, The Orthodox Church, 4. bölüm.

67 H. G. B. Teule, "Ta'rikh: Christian Arabic Historiography”, Encyclopaedia of Islam (Supplement) (Leiden: Brill, 2000-2002), 12/807-809, tartışılan eserler hakkında kapsamlı bir kaynakça ile beraber bkz. N. M. El Cheikh, "The Contribution of Christian Arab Historians to Muslim Historiography on Byzantium", Bulletin of the Royal Institute for Inter-Faith Studies 1 (1999), 45-60.

68 R. Pearse, Agapius of Hierapolis: Universal History (Tertullian Project website, http://www.tertullian.org/fathers/index.htm\#Agapius Universal History, 2008); Lamoreaux in Noble ve Treiger, The Orthodox Church, 5. bölüm.

69 Graf, Geschichte, 3/306-307, 361-377.

70 H. Bualuan, “Mikha'il Breik, a Chronicler and Historian in 18th Century Bilad al-Şam”, Parole de l'Orient 21 (1996), 257-70; S. Tamari, Miha'il Burayk (Historians of the Ottoman Empire database, http://www.ottomanhistorians.com/database/html/burayk en.html, 2007)

71 L. Cheikho, Arabic Christian Poets before and after Islam [in Arabic] (Piscataway: NJ: Gorgias Press, 2008) 
ise Fatımî hükümdarı Hâkim'in zulüm dönemi boyunca yazan, on birinci yüzyıl Arap Ortodoks şair ve teoloğu, Gazze Piskoposu Süleyman'dır. Süleyman'ın şiirleri onun enkarnasyonun gizemindeki coşkusunu ifade etmekte, oğlunun ölümüne ağıt yakarken aynı zamanda Hristiyanlığın Filistin'deki kutsal mekânlarını da övmektedir. ${ }^{72}$ Arap Ortodoks olan Antakya Patriği Macarios'un (dönemi: 1647-1672) seyahatleri, oğlu ve yardımcısı baş diyakoz Halepli Pavlus (Paul of Aleppo) tarafından ustaca anlatıldı. ${ }^{73}$ 17. yüzyılda Suriye'de Arap Ortodoks kültürel rönesansında önemli bir figür olan Macarios, İstanbul üzerinden Rusya topraklarına Eflak'a ve Moldova'ya bu topraklardaki Ortodoks yöneticilerden malî yardım istemek için iki kez seyahat etti. Halepli Pavlus'un notları Ortodoks Kilisesi tarihi ve dönemin farklı Ortodoks toplulukları arasındaki ilişki hakkında paha biçilmez bilgiler sunmaktadır. Bundan başka Keldanî rahip İlyas el-Mevsılî’nin Güney Amerika yolculuğuyla ilgili olarak 17. yüzyıldan kalma seyahat notlarından da bahsedilebilir. ${ }^{74}$

Birinci derece önemi haiz olağanüstü çeşitlilik ve materyal zenginliği gösteren Hıristiyan Arap literatürü (tahminen yüzde doksanı henüz herhangi bir dilde yayımlanmamış durumda!) okuyucularını beklemekte; kilise tarihi ve Orta Doğu hakkındaki düşünce şeklimizi değiştirecek belki de devrim yaratacak önemli keşifler vadetmektedir.

72 Noble-Treiger, The Orthodox Church, 6. bölüm.

73 F. C. Belfour, Travels of Macarius, Patriarch of Antioch (London: Oriental Translation Fund., 1835-1837); H. Kilpatrick, "Journeying towards Modernity: The Safrat al-Batrak Makariyus of Bulus ibn al-Za'im al-Halabi", Die Welt des Islams, 37/2 (1997), 156-177; Feodorov in Noble-Treiger, The Orthodox Church, 12. bölüm.

74 N. I. Matar, In the Lands of the Christians: Arab Travel Writing in the 17th Century (New York: Routledge, 2002), 45-111; H. Kilpatrick, “Journeying towards Modernity”, 174-76. 


\section{Kaynakça}

Abullif, W. "Les sources du Mağmu' usul al-din d'al-Mu'taman ibn al-'Assal". Parole de l'Orient 16 (1990-91), 227-38.

Abullif, W. Dirasa 'an al-Mu'taman ibn al-'Assal wa-kitabihi "Majmu' usul al-din" watahqiqihi. Jerusalem: Franciscan Printing Press, 1997.

Albert, M. vd. Christianismes orientaux: Introduction a l'étude des langues et des littératures. Paris: Les Éditions du Cerf, 1993.

Al-Mu'taman ibn al-'Assal. Majmu' usul al-din [Summa dei principi della Religione]. çev. B. Pirone. ed. W. Abullif. Jerusalem: Franciscan Printing Press, 1998-2002.

Beaucamp, J. vd. "La persecution des chretiens de Nagran et la chronologie himyarite". ARAM 11-12 (1999-2000), 15-83.

Beaumont, M. "Ammar al-Basri on the Incarnation". Christians at the Heart of Islamic Rule: Church Life and Scholarship in 'Abbasid Iraq. ed. D. Thomas. 55-63. Leiden: Brill, 2003.

Travels of Macarius, Patriarch of Antioch. çev. F. C. Belfour. London: Oriental Translation Fund, 1835-37.

Bitar, T. Al-Qiddisun al-mansiyyun fi al-turath al-Antaki. Duma-Lebanon: Manshurat alNur, 1995.

Brock, S. "From Qatar to Tokyo, by Way of Mar Saba: The Translations of Isaac of Beth Qatraye (Isaac the Syrian)". ARAM 11-12 (1999-2000), 475-84

Brock, S. "Syriac Authors from Beth Qatraye". ARAM 11-12 (1999-2000), 85-96.

Bualuan, H. "Mikha'il Breik, a Chronicler and Historian in 18th Century Bilad al-Šam". Parole de l'Orient 21 (1996), 257-70.

Cheikho, L. Arabic Christian Poets before and after Islam [in Arabic]. Piscataway: NJ: Gorgias Press, 2008.

Ciggaar, K.-Metcalf, M. (ed.). East and West in the Medieval Eastern Mediterranean: Antioch from the Byzantine Reconquest until the End of the Crusader Principality. 1. Cilt. Leuven: Peeters, 2006.

Coquin, R.-G. "Arabic Christian Literature". The Encyclopedia of the Middle Ages. ed. Andre Vauchez. 1/91-93. Cambridge: J. Clarke \& Co., 2000.

Courbage, Y.-Fargues, P.. Christians and Jews under Islam. London and New York: I. B. Tauris, 1997.

Davis, S. J. "Introducing an Arabic Commentary on the Apocalypse: Ibn Katib Qaysar on Revelation". Harvard Theological Review 101 (2008), 77-96.

Dick, I. Melkites: Greek Orthodox and Greek Catholics of the Patriarchates of Antioch, Alexandria and Jerusalem. Boston: Sophia Press, 2004.

Djobadze, W.. Archaeological Investigations in the Region West of Antioch on-the-Orontes. Stuttgart: Franz Steiner, 1986.

Ebied, R. Y.-Teule, H. G. B. (ed.). Studies on the Christian Arabic Heritage in Honour of Father Prof. Dr. Samir Khalil Samir S.I. at the Occasion of his Sixty- Fifth Birthday. Leuven: Peeters, 2004.

Ebied, R. Y.-Thomas, D. (ed.). Muslim-Christian Polemic during the Crusades: The Letter from the People of Cyprus and Ibn Abi Talib al-Dimashqi's Response. Leiden: Brill, 2005.

El Cheikh, N. M.. “The Contribution of Christian Arab Historians to Muslim Historiography on Byzantium". Bulletin of the Royal Institute for Inter-Faith Studies 1 (1999), 45-60.

Endress, G. The Works of Yahya ibn 'Adi: An Analytical Inventory. Wiesbaden: Reichert, 1977. 
Fattal, A. Le statut légal des non-musulmans en pays d'Islam. Beirut: Imprimerie Catholique, 2. Baskı, 1995.

Ferrari, C. (çev. ve ed.). Der Kategorien kommentar von Abu l-Farağ'Abdallah ibn at-Tayyib: Text und Untersuchungen. Leiden: Brill, 2006.

Fiey, J. M. Chrétiens syriaques sous les Mongols (Il-Khanat de Perse, XIIIe- XIVe s.). Leuven: Secrétariat du Corpus SCO, 1975.

Grabar, O. The Dome of the Rock. Cambridge: MA: Belknap Press, 2006.

Graf, G. Geschichte der christlichen arabischen Literatur. 5 cilt. Vatican: Biblioteca Apostolica Vaticana, 1944-1953.

Graf, G. Christlicher Orient und schwäbische Heimat: Kleine Schriften, anlässlich des 50. Todestags des Verfassers. ed. H. Kaufhold, Ergon-Verlag in Kommission. 2 Cilt. Beirut and Wurzburg, 2005.

Griffith, S. "Ammar al-Basri's Kitab al-burhan: Christian Kalam in the First Abbasid Century". Le Museon 96 (1983), 145-81.

Griffith, S. Arabic Christianity in the Monasteries of Ninth-Century Palestine. Aldershot: Ashgate, 1992.

Griffith, S. Syriac Writers on Muslims and the Religious Challenge of Islam. Kottayam: SEERI, 1995.

Griffith, S. (çev.). A Treatise on the Veneration of the Holy Icons. by Theodore Abu Qurrah. Leuven: Peeters, 1997.

Griffith, S. "Melkites," "Jacobites" and the Christological Controversies in Arabic in Third/Ninth-Century Syria". Syrian Christians under Islam: The First Thousand Years. ed. D. Thomas. 9-55. Leiden: Brill, 2001.

Griffith, S. The Beginnings of Christian Theology in Arabic: Muslim-Christian Encounters in the Early Islamic Period. Aldershot: Ashgate, 2002.

Griffith, S. (çev.). Yahya ibn 'Adi: The Reformation of Morals. Provo: UT: Brigham Young University Press, 2002.

Griffith, S. "The Church of Jerusalem and the "Melkites": The Making of an "Arab Orthodox" Christian Identity in the World of Islam, 750-1050". Christians and Christianity in the Holy Land. ed. O. Limor -G. G. Stroumsa. 173-202. Turnhout: Brepols, 2006.

Griffith, S. "Christians, Muslims and the Image of the One God: Iconophilia and Iconophobia in the World of Islam in Umayyad and Early Abbasid Times", Die Welt der Gotterbilder. ed. B. Groneberg-H. Spieckermann. 347-380. Berlin and New York: Walter de Gruyter, 2007.

Griffith, S. "Syriacisms in the "Arabic Qur'an": Who Were Those Who Said "Allah Is Third of Three" according to al-Ma'ida 73?". A Word Fitly Spoken. ed. M.M. Bar-Asher vd. 83110. Jerusalem: Mekhon Ben-Tsevi le-heker kehilot Yisra'el ba-Mizrah, 2007.

Griffith, S. The Church in the Shadow of the Mosque: Christians and Muslims in the World of Islam, NJ: Princeton University Press, Princeton, 2008.

Griffith, S. "Hunayn ibn Ishaq and the Kitab adab al-Falasifah: The Pursuit of Wisdom and a Humane Polity in Early Abbasid Baghdad". Malphono w-Rabo d-Malphone: Studies in Honor of Sebastian P. Brock. ed. G. Kiraz. 135-60. Piscataway: NJ: Gorgias Press, 2008.

Gutas, D. Greek Thought, Arabic Culture: The Graeco-Arabic Translation Movement in Baghdad and Early Abbasid Society (2nd-4th/5th-10th centuries). London: Routledge, 1998. 
Gyekye, K. (çev.). Arabic Logic: Ibn al-Tayyib's Commentary on Porphyry's "Eisagoge". Albany: NY: SUNY Press, 1979.

Haddad, R. La Trinité divine chez les théologiens arabes, 750-1050. Paris, Beauchesne, 1985.

Hage, W. Das orientalische Christentum. Stuttgart, Kohlhammer, 2007.

Hainthaler, T.. Christliche Araber vor dem Islam: Verbreitung und konfessionelle Zugehörigkeit. Leuven, Peeters, 2007.

Hourani, G. G.-Habachi, A. B.. “The Maronite Eremitical Tradition: A Contemporary Revival". Heythrop Journal 45 (2004), 451-465.

Hoyland, R. Seeing Islam as Others Saw It: A Survey and Evaluation of Christian, Jewish and Zoroastrian Writings on Early Islam. Princeton: NJ: Darwin Press, 1997.

Kaplony, A. The Haram of Jerusalem, 324-1099. Stuttgart: Franz Steiner, 2002.

Kassatly, H. La communauté monastique de Deir el Harf. Balamand-Lebanon: Universite de Balamand, 1996.

Keating, S. T. Defending the "People of Truth" in the Early Islamic Period: The Christian Apologies of Abu Ra'itah. Leiden: Brill, 2006.

Kennedy, H. Antioch: From Byzantium to Islam and Back Again. The Byzantine and Early Islamic Near East, Essay VII. Aldershot: Ashgate, 2006.

Kilpatrick, H. "Journeying towards Modernity: The Safrat al-Batrak Makariyus of Bulus ibn al-Za'im al-Halabi”. Die Welt des Islams 37/2 (1997), 156-77.

Korobeinikov, D. "Orthodox Communities in Eastern Anatolia in the Thirteenth and Fourteenth Centuries, Part I". Al-Masdq 15/2 (2003), 197-214.

Korobeinikov, D. "Orthodox Communities in Eastern Anatolia in the Thirteenth and Fourteenth Centuries, Part II". Al-Masaq 17/1 (2005), 1-29.

Krivov, V. V. "Arab-Christians in Antioch in the Tenth-Eleventh Centuries [in Russian]". Traditions and Heritage of the Christian East. ed. D. E. Afinogenov-A. M. Muraviev. 247-255. Moscow: Indrik, 1996.

Lamoreaux, J. C. (çev.). Theodore Abu Qurrah. Provo: UT: Brigham Young University Press, 2005.

Lamoreaux, J. C.-Cairala, C. (ed. ve çev.). "The Life of Timothy of Kakhushta". Patrologia Orientalis 48/4 (2001). Brepols, Turnhout.

Leeming, K. "The Adoption of Arabic as a Liturgical Language by the Palestinian Melkites". ARAM 15 (2003), 239-46.

Levy-Rubin, M. "Arabization and Islamization in the Palestinian Melkite Community during the Early Muslim Period". Sharing the Sacred. ed. A. Kofsky-G. G. Stroumsa. 149-162. Jerusalem: Yad Izhak Ben Zvi, 1998.

MacEvitt, C. The Crusades and the Christian World of the East: Rough Tolerance. Philadelphia: University of Pennsylvania Press, 2007.

Matar, N. I. (çev.). In the Lands of the Christians: Arab Travel Writing in the 17th Century. New York: Routledge, 2002.

Matthew the Poor. Orthodox Prayer Life: The Interior Way. Crestwood: NY: St Vladimir's Seminary Press, 1983.

Matthew the Poor. Communion of Love. Crestwood: NY: St Vladimir's Seminary Press, 1984.

Michel, T. F. (çev.). A Muslim Theologian's Response to Christianity: IbnTaymiyya's alJawab al-Sahih. Delmar: NY: Caravan Books, 1984.

Morony, M. Iraq after the Muslim Conquest. Piscataway: NJ: Gorgias Press, 2005.

Morray, D. W. "The Defences of the Monastery of St Simeon the Younger on Samandag". Orientalia Christiana Periodica 60 (1994), 619-23. 
Nahas, G. N. "Le mouvement de la jeunesse Orthodoxe”. Proche-Orient Chretien 43 (1993), 69-81.

Nasrallah, J. “Couvents de la Syrie du Nord portant le nom de Siméon”. Syria 49 (1972), 127159.

Nasrallah, J. Histoire du mouvement littéraire dans l'Église melchite du Ve au XXe siècle. 2/2, 3/1, 3/2, 4/1, 4/2 Cilt. Leuven: Peeters, 1983-1989.

Nasrallah, J. Histoire du mouvement littéraire dans l'Église melchite du Ve au XXe siècle. ed. R. Haddad. 2/1 Cilt. Damascus: Institut français de Damas, 1996.

Noble, S.-A. Treiger, "Christian Arabic Theology in Byzantine Antioch: 'Abdallah ibn al-Fadl al-Antaki and His Discourse on the Holy Trinity", Le Muséon 124 (2011), 371-417.

Noble, S.-A. Treiger. The Orthodox Church in the Arab World (700-1700): An Anthology of Sources. DeKalb: Northern Illinois University Press, 2014.

O'Mahony, A. "Coptic Christianity in Modern Egypt", The Cambridge History of Christianity, Eastern Christianity. ed. M. Angold. 5/488-510. Cambridge: Cambridge University Press, 2006.

Osman, G. "Pre-Islamic Arab Converts to Christianity in Mecca and Medina". Muslim World 95/1 (2005), 67-80.

Pacini, A. (ed.). Christian Communities in the Arab Middle East: The Challenge of the Future. Oxford: Clarendon Press, 1998.

Panchenko, K. A. Blizhnevostochnoe Pravoslavie pod osmanskim vladychestvom: Pervye tri stoletija (1516-1831). Moscow: Indrik, 2012.

Papaconstantinou, A. "They Shall Speak the Arabic Language and Take Pride in It: Reconsidering the Fate of Coptic after the Arab Conquest". Le Museon 120/3-4 (2007), 273-99.

Pearse, R. (çev.). Agapius of Hierapolis: Universal History. Tertullian Project website: http://www.tertullian.org/fathers/index.htm\#Agapius_Universal_History, 2008.

Perier, A. (ed. ve çev.). Petits traités apologétiques de Yahya Ben 'Adi. Paris: J. Gabalda and P. Geuthner, 1920.

Pirone, B. (ed. ve çev.). Leonzio di Damasco: Vita di Santo Stefano Sabaita (725-794). Jerusalem: Franciscan Printing Press, 1991.

Polosin, V. V. vd. (ed.). The Arabic Psalter: A Supplement to the Facsimile Edition of Manuscript A187 “The Petersburg Arabic Illuminated Psalter". St Petersburg: Kvarta, 2005.

Portillo, R. D. “The Arabic Life of St. John of Damascus”. Parole de l'Orient 21(1996), 157-188.

Prawer, J. "Social Classes in the Crusader States: The "Minorities", A History of the Crusades, The Impact of the Crusades on the Near East. ed. N. P. Zacour-H. W. Hazard. 5/59-115. Madison: WI: University of Wisconsin Press, 1985.

Robinson, C. F. “Waraka b. Nawfal”. Encyclopaedia of Islam. 11/142-143. Leiden: Brill, 2. Bask1, 2000-2002.

Rubenson, S. "Translating the Tradition: Some Remarks on the Arabization of the Patristic Heritage in Egypt". Medieval Encounters 2 (1996), 4-14.

Samir, S. K. "Date de la composition de la "Somme theologique" d'al-Mu'taman b. al- Assal". Orientalia Christiana Periodica 50 (1984), 94-106.

Samir, S. K. "Christian Arabic Literature in the "Abbasid Period". Religion, Learning and Science in the 'Abbasid Period, The Cambridge History of Arabic Literature. ed. M. J. L. Young vd. 446-460. Cambridge: Cambridge University Press, 1991.

Samir, S. K. Rôle culturel des chrétiens dans le monde arabe. Beirut: CEDRAC, 2003. 
Samir, S. K.-Nielsen, J. S. (ed.). Christian Arabic Apologetics during the Abbasid Period (7501258). Leiden: Brill, 1994.

Sanders, J. C. J. (ed. ve çev.). "Ibn al-Tayyib: Commentaire sur la Génèse". Corpus Scriptorum Christianorum Orientalium, 274-75. Scriptores Arabici, 24-25. Leuven: Secrétariat du Corpus SCO, 1967.

Shahid, I. The Martyrs of Najran: New Documents. Brussels: Société des Bollandistes, 1971.

Shoshan, B. “Waba' [Plague]". Encyclopaedia of Islam. 11/2-3. Leiden: Brill, 2. Bask1, 20002002.

Swanson, M. N. “The Trinity in Christian-Muslim Conversation”. Dialog 44/3 (2005), 256-63.

Tamari, S. Miha'il Burayk. Historians of the Ottoman Empire database: http://www.ottomanhistorians.com/database/html/burayk en.html, 2007.

Teule, H. G. B. “Ta'rikh: Christian Arabic Historiography". Encyclopaedia of Islam. 12/807809. Leiden: Brill, 2000-2002.

Teule, H. G. B.-Schepens, V. “Christian Arabic Bibliography 1990-95”. Journal of Eastern Christian Studies 57 (2005), 129-74.

Teule, H. G. B.-Schepens, V. “Christian Arabic Bibliography 1996-2000". Journal of Eastern Christian Studies 58 (2006), 265-99.

Teule, H. G. B.-Schepens, V. “Christian Arabic Bibliography 2001-2005”. Journal of Eastern Christian Studies 62 (2010), 271-302.

Thomas, D. (ed.). The Bible in Arab Christianity. Leiden: Brill, 2007.

Thomas, D. "Arab Christianity". The Blackwell Companion to Eastern Christianity. ed. K. Parry. 1-22. Malden: MA: Blackwell, 2007.

Thomas, D.- B. Roggema-A. Mallett. Christian-Muslim Relations: A Bibliographical History. 4 Cilt. Leiden and Boston: Brill, 2009. (Devam ediyor)

Todt, K.-P. "Notitia und Diozesen des griechisch-orthodoxen Patriarchates von Antiocheia im 10. und 11. Jh.". Orthodoxes Forum 9 (1995), 173-85.

Todt, K.-P. "Region und griechisch-orthodoxes Patriarchat von Antiocheia in mittelbyzantinischer Zeit". Byzantinische Zeitschrift 94 (2001), 239-67.

Todt, K.-P. “Griechisch-Orthodoxe (Melkitische) Christen im zentralen und südlichen Syrien ... (635-1365)". Le Muséon 119/1-2 (2006), 33-88.

Treiger, A. "New Evidence on the Arabic Versions of the Corpus Dionysiacum". Le Museon 118 (2005), 219-40.

Treiger, A. “The Arabic Version of Pseudo-Dionysius the Areopagite's Mystical Theology, Chapter 1". Le Museon 120 (2007), 365-93.

Troupeau, G. "La littérature arabe chrétienne du Xe au XIIe siècle". Cahiers de civilisation médiévale i4 (1971), 1-19.

Troupeau, G. Études sur le christianisme arabe au Moyen Âge. Aldershot: Ashgate, 1995.

Wasserstein, D. J. "Why Did Arabic Succeed Where Greek Failed? Language Change in the Near East after Muhammad". Scripta Classica Israelica 22 (2003), 257-72.

Wisnovsky, R. "New Philosophical Texts of Yahya ibn 'Adi: A Supplement to Endress' Analytical Inventory". Islamic Philosophy, Science, Culture, and Religion: Studies in Honor of Dimitri Gutas. ed. F. Opwis-D. Reisman. 307-326. Leiden and Boston: Brill, 2012.

Yakushev, M. I. "On the Restoration of the Rule of Arab Patriarchs in the Patriarchate of Antioch [in Russian]". Lomonosovskie Chtenija, Vostokovedenie. 374-379. Moscow: Akademija Gumanitarnykh Issledovanij, 2006.

Zaborowski, J. R. "From Coptic to Arabic in Medieval Egypt". Medieval Encounters 14/1 (2008), 15-40. 
Zanetti, U. "Tradition et modernité dans l'Église copte", Traditions and Heritage of the Christian East. ed. D. E. Afinogenov-A. M. Muraviev. 221-238. Moscow: Indrik, 1996. 